\title{
Anti-war movements-heading for a 60s revival?
}

\section{David Dickson reports from California on how critics of US military policy are beginning to tap the grass-roots energy of the anti-nuclear movement}

IT might have become a formula for instant nostalgia. But when the film version of the 1960s anti-war musical Hair opened in California a few weeks ago, it was reviewed-and widely praised-at face value, with few claiming that its sentiments belonged to the previous decade. And taken with the success of two other anti-war films in last week's Oscar awards, the popularity of Hair suggests that these sentiments remain close to the surface.

In Washington, concern about the security of Middle East oil supplies is already generating the type of discussion about 'protecting natural interests' that preceded the military intervention in Vietnam. And a question now being debated on many campuses throughout the US is whether opposition to a growing military budget and to an increasingly hawkish administration is likely to coalesce into something comparable to the anti-war movements of the $1960 \mathrm{~s}$.

To judge from the situation in California, such a coalescence may not be too far away. At present, various groups are concentrating on a number of different objectives, some only distantly related to one another. But growing concern about US military policy in general-together with unease about nuclear energy in all its forms after the Harrisburg accident-are beginning to draw these groups together

Some of the more recent events include:

- At the University of California's Berkeley campus, a senate policy committee has recommended that the university sever all links with its Lawrence Livermore and Los Alamos laboratories, claiming that the large proportion of the activities of the two laboratories devoted to weapons research make the involvement of the university--currently responsible for the management of each-" "totally inappropriate".

- A number of Californian and antinuclear groups are expected to take part in demonstrations outside the university demanding that the laboratory's skills and resources be turned "totally towards peaceful research" as a way of putting the cap on the arms race.

- At Stanford University, a group of students is mounting a campaign to oppose legislation being discussed in Washington for revising the draft. One of the first speakers to address a university meeting on the issue was David Harris, student president in 1966 67 who spent 20 months in prison for draft evasion.

- A number of requests has been received by the American Association for the Advancement of Science to place public discussion of the US military budget and its implications on the agenda of next year's annual meeting in San Francisco.

- A Bærkeley group has published, through the Washington-based Institute for Policy Studies, a pamphlet on "resurgent militarism", claiming that "all struggles for social progress must confront the new militarism", and that otherwise "the likelihood of nuclear war will surely increase".

Such concerns are by no means confined to the West Coast. At a national level, church and religious leaders have, in particular, put military spending at the top of their agenda of items of social concern, both on a national and an international basis

Similarly anti-nuclear groups, once concerned primarily with the safety parameters of energy policies, are making the links to military policy. "If you've done your homework you know you cannot separate the two issues" says Marta Daniels of the Trident Conversion Campaign, the sponsors of a mass demonstration in Groton, Connecticut two weekends ago at which 229 persons were arrested for trying to block shipyard entrances to guests arriving for the launch of a new nuclear submarine.

But it seems to be on the West Coast, with its high concentration of both defence-related industries and veterans of the anti-Vietnam campaigns, where the linkages are being most tightly drawn.

One focus in particular has been the relationship between the University

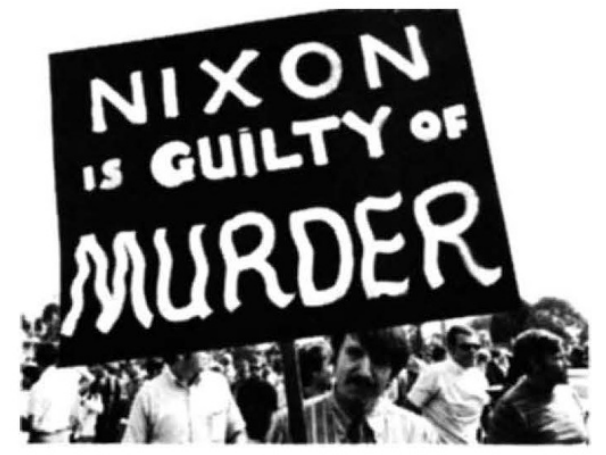

Now nuclear power is seen as the guilty party.

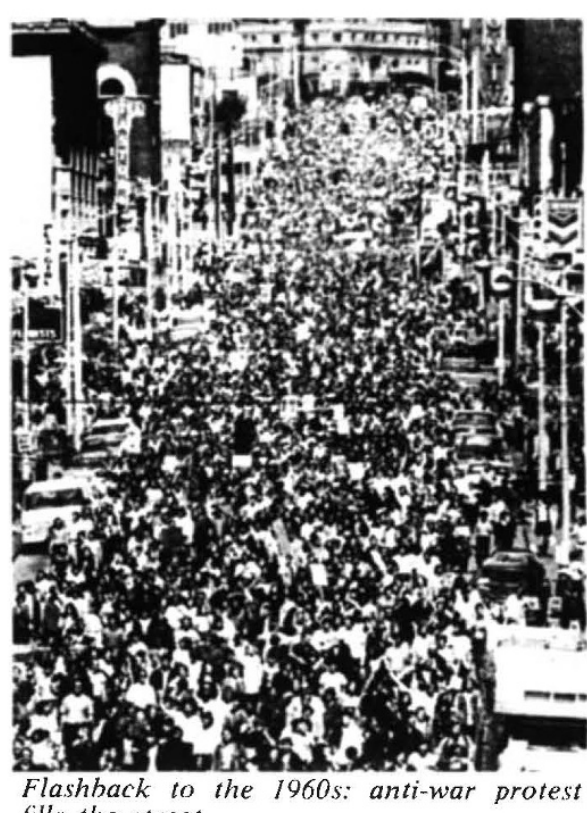

fills the street.

of California and the two weapons laboratories which it manages for the Department of Energy. This link has long been a source of contention among university faculty and students and moves to sever it in recent years have been given a boost by a broader antimilitarism campaign.

Supporters of the current arrangement argue that being run by the university means the laboratories can both maintain the high quality of their scientific research, and remain free of industry or Washington-dominated influences to express their views. "The university connection is the best way to serve the people" says Ed Hammel of the Los Alamos laboratory.

Critics point out that every nuclear weapon in the US armoury was conceived, developed and tested by the two laboratories. "The laboratories are not academic institutions, they epitomise "science with a purpose", says one long-time opponent, Professor Charles Schwarz of Berkeley's Department of Physics.

Ironically, those on both sides of the debate agree that, despite wide disparaties in the technology, concern over the health hazards of nuclear power have linked the energy and weapons issues together in the public's mind.

Dr David S. Saxon, President of the University of California, sees public attitudes on both as a source of concern-hut a situation for which scientists must share part of the blame. "The present unreasoning fear within this country and abroad of anything associated with the word nuclear is a reflection of an almost inexcusable failure within the scientific and pro- 
fessional community involved in nuclear energy", he said recently.

"There has been a consistent unwillingness to react in responsible ways to the questions that members of the public ask. In too many instances the official attitude has been overbearing, arrogant and intolerant."

Dr Schwarz, on the other hand, feels that the type of concerns raised by the Harrisburg incident may-legitimately --spill over to what he considers a far greater health issue, namely the spread of nuclear weapons. "We have to show that the same institutions that run the nuclear power programme also run the nuclear weapons programme-and that we have been told the same lies. I an not against nuclear power in itself, but I am opposed to it because, as with nuclear weapons, I don't trust the people in control of it at the present time".

The university has itself been reconsidering its relationship to the two laboratories. A committee established in 1977 under the chairmanship of $\mathrm{Dr}$ William Gerberding. Chancellor of the University of Illinois, issued a report last year, suggesting that the university should continue to manage the laboratories, but through the operation of a powerful board appointed by the university, which would play a much closer role in overseeing the operation of the two laboratories than under present arrangements.

In an attempt to counteract charges that even under a board such as that proposed by the Gerberding committee, there would be little public discussion of the laboratories' activities, one university vice-president, Dr William Fretter, has proposed as an alternative arrangement the establishment of an advisory council to the university president, containing scientists, faculty' members and students.

"I did not find the Gerberding proposals realistic, since the programmes of the laboratories-especially the weapons laboratories-are determined in Washington by the federal government, and it seemed unrealistic that these could be influenced substantially by a university committee', Dr Fretter said last week.

He argues that although the committec which he has proposed would only be an advisory one, it should operate in public "since both the university community and the general community need more information on what goes on in the laboratories" Critics such as Dr Schwarz, however, maintain that since the committee would not deal with the laboratories' classified activities, and since it wouid have no executive responsibility-which would remain in the hands of President Saxon-it would lack any real teeth, and hence be little improvement on the current situation.

Debate within the university on the future relationship to the laboratories has been put temporarily on ice following the announcement in December that the Department of Energy was itself planning a review of the current arrangements. The department's report is due to be presented to Energy Secretary James Schlesinger next month, and is awaited with interest (particularly since, although being prepared by a subcommittee, the report is officially to be submitted by DOE's Energy Research Advisory Board-and this contains a number of individuals from the public interest community as specialists in alternative energy sources)

But if there is a pause in the official debate, grass-roots opposition is continuing to grow. The future of the weapons laboratories was among the issues raised at a mass rally held in San Francisco two weeks ago to protest at the opening of the Diablo Canyon nuclear power plant in the state, a meeting held under the shadow of the Harrisburg incident. And organisers of next month's demonstration at Livermore predict many thousands will turn up for a mass march, rally and 'peace conversion fair', with groups fasting at the laboratory gates, and others walking to the laboratory from all over California.

To judge from reactions elsewhere such activities are unlikely to be warmly welcomed by the university authorities. Last week a film crew was thrown out of Harvard University while trying to make a film about the 1960 s protest movement. The film's director, Mr Jim Zinneman. admitted that a three-story' mural showing some American soldiers trampling on Vietnamese "upset some faculty members and alumni". Nostalgia is not what is used to be.

\section{ISABELLE team denies setback}

RUMOURS that the US ISABELLE project is having difficulties producing superconducting magnets for its $400 \mathrm{GeV}$ proton-proton storage rings were denied last week by Dr Jim Sanford, the project head. In an interview with Nature, he said there were no problems with quadropole magnet production, although they had run into difficulties with the dipole magnets.

Overall, progress was " $90 \%$ satisfactory". "We are having problems in meeting the ultimate field of 5 teslas. We have reached 5 teslas in a model but not in the production prototypes. They are operating now at around $4 \frac{1}{2}$ teslas," he said.

The dipole magnets were first designed to operate at 4 teslas. The team made 13 model magnets and most of these exceeded this field. Recently the design was modified to operate at 5 teslas, and one model reached 5.1 teslas. However, when this was put into production, the magnets only achieved

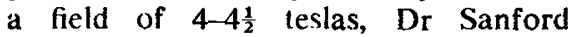
said. "We are not entirely sure what is causing this probelm. Maybe it is the materials in the superconducting braid. We wanted to have a bigger margin than 5.1 teslas and so we added more niobium-titanium in the production, and in the process we may have lost some of the stability of the materials."

Production of the superconducting magnets is the major technological challenge of the ISABEI.LE project. The project has already had one setback - the US Department of Energy will only fund ISABEL.L.F over seven years and not the five years the scientists had hoped for. However, Dr Sanford is confident the magnet problem will be solved by the summer so the contract for production can be issued by the end of the year. This will keep ISABELLE on schedule, and may even provide an argument for advancing to a 5-year target, said Dr Sanford.

In Europe. ISABELLE's competition in the race to produce the heavy intermediate vector boson, the CERN proton-antiproton experiment. is expected to produce hard evidence by 1982, said a CERN spokesman.

\section{UK and Sweden attack lead poisoning studies}

A NEW US report on lead pollution published in The New England Journal of Medicine by a team of researchers from Harvard Medical School and the Children's Hospital in Boston has not been openly welcomed in Britain.

The study indicates that currently accepted lead levels may be set far too high to be safe for children in urban areas. The team, headed by Dr Herbert Needleman, examined lead levels in children's milk teeth, which is considered to be a better indicator of long term exposure than blood lead levels.

Starting with a sample of 3,329 children, two samples matched for social and environmental variables including social class, mother's age and parental IQ were constructed. The $\mathbf{5 8}$ high lead children (20ppm in dentine) and the 100 low lead children (less than 10ppm) were given standard psychological and mental tests. (The mean blood lead levels in the two groups were $355 \mu \mathrm{g} / 1$ and $238 \mu \mathrm{g} / 1$, both of which are well within the normal range for children in UK urban areas.) 